\title{
TRAITOR TO LIVONIA? THE TEUTONIC ORDERS' LAND MARSHAL JASPER VAN MUNSTER AND HIS ACTIONS AT THE OUTSET OF THE LIVONIAN CRISIS, 1554-1556
}

\author{
KEYWORDS
}

Teutonic Order; Livonian Confederation; $16^{\text {th }}$ century; tsar Ivan Grozny; PolandLithuania; Livonian Crisis; Coadjutor feud; Archbishop of Riga

\section{INTRODUCTION}

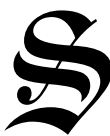

hortly after the middle of the sixteenth century, the Livonian Confederation, which for a long time had held together the territories of what is now Latvia and Estonia, endured a series of devastating wars, by which its existence would come to an end. ${ }^{1}$ As a combination of a military order's lordship, four secular bishoprics, and several important towns the Confederation proved incapable of defending itself. In the end, it had to give up its autonomy, and it was split up in three parts that were annexed or came to be dominated by the former Confederation's great neighbouring powers: Russia, Poland and Sweden. The crushing defeat dealt by the Russians to the Confederation at the battle of Ermes on 2 August 1560 heralded the end for the Livonian branch of the Teutonic Order. ${ }^{2}$ As a result

1 A first version of this paper has been published (in Dutch): J. A. Mol, Vechten, bidden en verplegen. Opstellen over de ridderorden in de Noordelijke Nederlanden, Hilversum 2011. I would like to thank Michael Douma for correcting the English translation.

On the history of the Baltic region in the sixteenth century in general see D. Kirby, Northern Europe in the Early Modern Period. The Baltic World 1492-1772, London 1990, p. 44 sqq. Cf. R. Wittram, Baltische Geschichte. Die Ostseelände Livland, Estland, Kurland 1180-1918, München 1954, pp. 64-72.

2 The end of the Livonian branch of the Teutonic Order is usually connected with Gotthard Kettler's withdrawal as Livonian Master at the beginning of 1562: K. Militzer, Die Geschichte des Deutschen Ordens, Stuttgart ${ }^{12005}$, pp. 156-167. 
of the defeat, the political structure of the region underwent a profound change. The loss of a unifying central authority created a power vacuum, and gave rise to the so-called "Baltic question" the persistent concern over who would control the political fate of the region.

The war with Russia came as no surprise to the Livonian Confederation. Shortly after 1500, the Master of Livonia, Wolter von Plettenberg, had managed to repel forces of the Grand Duke Ivan III, but this was accomplished only with herculean effort. But fifty years later, a new, more menacing threat appeared as Moscow under the leadership of Ivan IV sought to gain access to the Baltic Sea. From the west as well, the United Kingdom of Poland and Lithuania, along with its vassal state of Prussia were interested in acquiring Livonian territories bordering Lithuania. Denmark and Sweden, too, were preparing strategic offenses to address their age-old political conflicts over control of what is now Estonia. All parties in Livonia had to account for these neighbours' ambitions. This was true for the two most important powers in particular: the Teutonic Knights and the archbishop of Riga.

One of the most prominent leaders of the Order at that time was the Dutchborn land marshal Jasper van Munster. In all military orders, the marshal was traditionally the leader and supreme commander during times of war, and as a consequence, he was an important figure in the Order's hierarchy. This was also the case within the Livonian branch of the Teutonic Order. Jasper van Munster had been appointed land marshal in 1551. Van Munster's two predecessors as land marshal had each subsequently risen to the position of Livonian Master, and Van Munster was therefore considered to be the pre-eminent candidate to succeed the old Master Heinrich von Galen. Van Munster was convinced that Livonia could only maintain itself as a political entity if it entered into a prolonged alliance with the United Kingdom of Poland and Lithuania, accepting the risk that this might mean a partial sacrifice of its autonomy. However, Van Munster failed to gain enough support for the plan. He was accused of treason, and was forced to flee to Lithuania in May 1556, where he remained in exile, only returning to Livonia at the end of the sixties.

An interesting aspect to Jasper van Munster's political course is that the last Master of Livonia, Gotthard Kettler, in the end also supported a protective alliance with Poland. In 1562, just after he had dissolved the Livonian Order, Kettler succeeded in creating a small duchy, Courland, where he accepted the Polish king as his sovereign more or less in imitation of Albrecht of Brandenburg who had more than three decades earlier managed to secularize the Order state of Prussia in 1525 This begs the question as to why Jasper failed in reaching his political aims whereas - in hindsight - his choice for a Polish alliance had been strategi- 
cally sound. Although Jasper van Munster receives mention in most studies of the sixteenth-century history of the Baltic regions, his actions have not been subject to thorough review. Baltic-German historiography from the nineteenth and early twentieth century played its part in neglecting this topic, as scholars saw little reason to question the Order's portrayal of Van Munster as a traitor who would have ruined Livonia for personal gain. ${ }^{3}$ The well-known journalist and historian Ernst Seraphim, for instance, said that Van Munster appeared “[...] wesentlich von persönlichen Gesichtspunkten geleitet [...] zu sein".

However, sources have become available that allow us to identify and more thoroughly explain Van Munster's politics, and his heritage and familial interests. The most significant of these sources are a collection of letters from the archive of Duke Albrecht of Brandenburg-Ansbach from the years of 1534-1576. These have been made accessible in the past decade by the Berliner archivist Stefan Hartmann. ${ }^{5}$ Hartmann's six volumes of excerpts contains several hundreds of texts concerning Van Munster. Significant source material also can be found in a Polish set of volumes that are concerned with the relationship between the kingdom of Poland and the duchy of Prussia. ${ }^{6}$ Finally some fifteen letters by Van Munster to his cousin Johan van Ewsum are available at the Groningen archive of the Ewsum family. My article will show how and why Jasper van Munster was driven to turn against Heinrich von Galen and go into exile in Lithuania, and why it took him so long before he managed to get some rehabilitation and retribution after Poland set out the terms for the peace of Poswol to the new master Wilhelm von Fürstenberg on 14 September, 1557.

3 Th. Schiemann, Russland, Polen und Livland bis ins 17. Jahrhundert, 2 vols, Berlin 1886-1887, here vol. 2, pp. 286-287.

4 E. Seraphim, Geschichte von Livland, vol. 1: Das livländische Mittelalter und die Zeit der Reformation (bis 1582), Gotha 1906, pp. 214-215. Seraphim and Schiemann apparently thought that Jasper, when he once had succeeded in becoming Master, would have strived to transform the Order's state and the rest of Livonia into a secular principality with the king of Poland as his liege lord, just like Albrecht of Brandenburg had done with Prussia. This vision seems to have been based on the judgment of the late sixteenth-century chroniclers Johannes Renner and Salomon Henning, who were partygoers of Jaspers adversaries Wilhelm von Fürstenberg and Gotthard Kettler respectively.

5 Herzog Albrecht von Preussen und Livland. Regesten aus dem Herzoglichen Briefarchiv und den Ostpreussischen Folianten (1525-1570), 7 vols, ed. S. Hartmann, U. Müller, Köln-WeimarWien 1996-2008.

6 Documenta ex Archivo Regiomontano ad Poloniam spectantia, 40 vols, ed. C. Lanckorońska, Rome 1973-2013. 


\section{ORIGIN AND DESCENT}

To better understand Van Munster's actions we need to start with a review of his earlier life. His exact year of birth remains unknown, but choosing 1501 or 1502 is a decent guess. ${ }^{7}$ He had two brothers: the elder Roelof, and the younger Jurgen, which made him the middle son of the Drenthe-Westfalian nobleman Roelof van Munster and a Groningen-Frisian nobleman's daughter Bauwe van Heemstra. ${ }^{8}$ Roelof van Munster was the youngest son of Hendrik van Munster, who had inherited the (sole) Drentish lordship of Ruinen from his mother Johanna, heiress to Ruinen. ' Hendrik's father Berend, in turn, was from Westphalia originally, and through marriage to Johanna had moved into the territory of the prince-bishop of Utrecht.

Jasper's father Roelof had been an exceptionally ambitious man. ${ }^{10}$ Though, being a younger son, he could not succeed his father (Berend) as lord of Ruinen, he managed to be appointed bailiff of Drenthe by the prince-bishop of Utrecht in 1506. This was an important office, because the bailiff was not only entrusted with the regional administration and the stewardship of the bishop's estates, but he also acted as lord of the castle of Coevorden, where he supervised the levying of tolls. Roelof strove for lower taxes due to the bishop and more regional autonomy, to strengthen his position as Drenthe's intermediary lord. In 1509, to buttress his control, he bought the strategically situated estate "Kinkhorst" near Meppel on the north shore of the IJssel-delta, and expanded it on his own initiative into a robust castle. One can imagine this usurpation of powers did not please the bishop. The nearby cities of Kampen, Deventer and Zwolle, all along the IJssel River, were also bothered by these developments, since they feared that Van Munster could become a robber baron. To block Van Munster's political aims, the IJsel-cities joined together to lay siege to the Kinkhorst in 1511, destroying it and subsequently razing it to the ground.

As the Kinkhorst fell, Roelof Van Munster escaped to Coevorden and directed a feud against his liege lord by plundering parts of Overijssel. Under great pressure

7 In 1552 he is recorded to have been 50 years old; in August 1563 he is characterized as an elderly man of c. 60 years: Regesten (as n. 5), nos 2135, 2145, 3246.

8 About Jasper's famlily see E. G. v. Münster, Die grafen von Münster. Familienkundliche Notizen 1100-1980, Schwäbisch Gmünd 1981, p. 94 sqq. Cf. O. D. J. Roemeling, De afstamming van Aline Ovingh, De Nederlandsche Leeuw 86 (1969), cols 157-174.

9 Repertorium op de Overstichtse en Overijsselse leenprotocollen 1379-1805, 7 vols, here vol. 7, ed. E. D. Eijken, Zwolle 1995, no 1698.

10 C. A. van Kalveen, Het bestuur van bisschop en Staten in het Nedersticht, Oversticht en Drenthe, 1483-1520, Utrecht 1974, pp. 220-265. 
from various parties he decided to withdraw from Coevorden in the late summer of 1512. Because the compensations he was paid by the bishop were not to his liking, Van Munster made himself master of the castle of Coevorden again in October, after which he took vengeance on his lord by terrorising the countryside of Salland, Twente and Drenthe. In December of 1514, an armed force of the bishop chased Van Munster out of Coevorden. He then was dishonourably and without recompense fired from all his functions. He fled with his wife to East Frisia to serve under Count Edzard, who was on friendly terms with the duke of Guelders and who was openly hostile to a mutual enemy of Van Munster, namely the bishop of Utrecht. Although all his rights and holdings in Drenthe had been taken from him, Roelof van Munster was not reduced to poverty by any means. Presumably financed by the booty he had acquired in his raids, he was able to afford a loan of 3,300 guilders to the city of Groningen in $1514 .{ }^{11}$ Furthermore, after 1515 he was able to derive income from the estate of Herzford (Harsevoort) near Lingen on the Ems, which was a fief of the bishop of Münster. ${ }^{12}$ Because his eldest son and wife are listed as new fief-holders for Herzford ${ }^{13}$ in 1519 , it can be presumed that Roelof Van Munster died that year. ${ }^{14}$ His widow acquired the manor Duirsum near Loppersum in $c .1524^{15}$, Roelof Van Munster's two sons, Jasper and his eldest brother Roelof survived. Roelof and his wife Maria van Selbach, daughter of a Guelders army captain ${ }^{16}$, lived in Duirsum until their deaths in 1558 and 1576 respectively, and were visited with some regularity by Jasper.

Meanwhile, Jurgen (also called Georg), Jasper's youngest brother, followed in his father's footsteps and those of his uncle Mencke van Heemstra ${ }^{17}$ by taking up soldiering as a profession. As a mercenary captain he first offered his services to the East Frisian 'Hauptling' (chieftain) Balthasar van Esens. After 1532 he was employed by the duke of Guelders, who gave him the castle of Wedde as a bond

11 Ibid., p. 261.

12 R. vom Bruch, Die Rittersitze des Emslandes, Aschendorf 1962, p. 155.

13 L. Hommes, Het geslacht Van Munster in Drenthe en Groningen van de $15^{\circ}-17^{\circ} \mathrm{eeuw}$, De Navorscher 97 (1958), pp. 24-30, here 26.

14 Kalveen (as n. 10), p. 489, n. 274, mentions that in these years Roelof did strike an alliance with King Christian II of Denmark, another enemy of the Utrecht bishop, to claim redress from the latter and the IJssel-towns for the destruction of the Kinkhorst, which did not lead to any results. After his death, Jasper and his brothers made several unsuccessful attempts to get compensation.

15 De Ommelander borgen en steenhuizen, ed. W. J. Formsma e.a., Assen ${ }^{2} 1987$, pp. 223-226.

16 J. J. van Weringh, De Selbachs, Gruoninga 1981, pp. 1-10.

17 Mencke, for that matter, took sides with George of Saxony against Guelders; together with Wigbold van Ewsum he belonged to the Groningen noblemen who were knighted by Duke George after the bloody capture of the town of Appingedam in 1514. 
in 1532, where he lived with his mother until they were forced to flee after the Guelders troops lost the battle of Heiligerlee in 1536. That he and his mother held a certain stature is evidenced by the property they had to take with them to Duirsum after Wedde had been taken by Georg Schenck of Tautenburg, stadtholder in support of Charles V. Mother Bauwe posessed demoiselles, pucelles et leurs joyaulx, bagues, accoutrement, or et argent et tout ce que leur compete (maids, jewellery, gold and silver). ${ }^{18}$

Like Roelof, Jurgen styled himself a 'Hauptling' in Duirsum and Den Ham, although he did actually not reside there. At the start of the forties he resided in Aurich, where he held the office of bailiff in the service of Countess Anne of East Frisia. In 1545 he inhabited the castle of Nienh(a)us in Aschendorf ${ }^{19}$ as bailiff of Emsland on behalf of the bishop of Münster, who in ecclesiastical matters also held authority over the northern and eastern part of the Groningen region. That is why the bishop of Münster could nominate Roelof for the position of provost of Loppersum, albeit without success, as opposing candidate Johan de Mepsche was appointed in 1543. In 1548 Jurgen was again bailiff in Aurich, a function he would maintain until his death in $1556 .{ }^{20}$ Meanwhile and thereafter, he was also active as the leader and organizer of mercenaries for local rulers in the northwest of the Holy Roman Empire and beyond. As such he will yet appear in Livonia later in this article.

In the 1540s and 1550s, both Jurgen and Jasper maintained intensive correspondence with the esquire Johan van Ewsum, then the centre figure of the epynomous wealthy Ewsum 'clan' of the Ommelanden. ${ }^{21}$ The Munster brothers were related to van Ewsum via his mother Beetke van Raskwerd, a daughter of Jasper van Munster's grandmother Biwe in den Ham, who had remarried to Asige van Raskwerd after the death of her first husband Abbe van Heemstra. Johan could therefore be addressed by the Munsters as dear cousin ("liebe Vedder"). He resided for a while at the Ewsumborg in Middelstum but after 1540 moved into the Mensinge manor in Roden. He, too, had been interested in the business of war since youth. For example, he had helped defeat the anabaptists in Münster in 1535, had volunteered for captain a year later to serve in a Habsburg campaign in Denmark. In the later engagement, little materialized, and notwithstanding his protestant sympathies, Johan joined Charles V's war against the Smalkaldic

18 De Ommelander borgen en steenhuizen (as n. 15), p. 224.

19 Gemeentearchief Groningen, Familiearchief Ewsum, no 132 (letters to Johan van Ewsum), 23.8.1545.

20 Gemeentearchief Groningen, Familiearchief Ewsum, no 132 (1.4. 1548).

21 M. Hartgerink-Koomans, Het geslacht Ewsum. Geschiedenis van een jonkersfamilie uit de Ommelanden in de $15^{e}$ en $16^{e}$ eeuw, Groningen 1938, pp. 134, 193. 
League in 1546 with two companies of footsoldiers under his command. Through letters and personal visits, Jurgen and Jasper remained in regular contact with Johan to discuss matter of martial enterprises, support for family members, money affairs and the like.

In brief, Jasper van Munster came from a well-to-do noble family which had served territorial lords for decades and had therefore grown accustomed to exercising authority at the regional level. His father's political aims had been to increase his sphere of influence at the cost of his liege lord the prince-bishop of Utrecht. But resistance from other powers had knocked the family from high ruling positions, sending it into Guelderian patronage and eventually into other pursuits. Thanks to their administrative experience, military skills, family ties and social capital, however, the Munsters nevertheless managed to maintain a powerful standing in the supra-regional social network of nobles of the North-Eastern Netherlands and the bordering regions across the Ems.

\section{JASPER'S CAREER UNTIL 1540}

How Jasper managed to join the Teutonic Order in Livonia is not quite clear. He must have been admitted c. 1518. ${ }^{22}$ The Livonian branch of the Teutonic Order had counted many men from Overijssel and Guelders amongst its members a century earlier, and possibly before that. One reason for this was because the Salland-born Cisse van den Rutenberg had made it to Livonian Master and subsequently had a large number of new order members recruited from his country of birth. ${ }^{23}$ This is why c. 1450 one of six knights of the Order in Livonia had originated from the Eastern Netherlands. But this connection had faded by 1500 . The career perspectives for the Dutch knights had become expressly unfavourable because of the increasing dominance of order members from Westphalia. Men from the Nedersticht, the Oversticht and Guelders, were seen as members of the Rhineland party, and these found themselves no longer eligible for higher offices after a Westphalian brother took office as Master of Livonia again in $1438 .{ }^{24}$ That

22 In an apologia from the beginning of 1558 Jasper states that he has faithfully served the order for 40 years: Regesten (as n. 5), no 3181.

$23 \mathrm{~J}$. A. Mol, Nederlandse ridderbroeders van de Duitse orde in Lijfland; herkomst, afkomst en carrières, Bijdragen en Mededelingen betreffende de Geschiedenis der Nederlanden 111 (1996), pp. 1-29, here 18 .

24 Ibid., pp. 23-24. 
Jasper was admitted c. 1518 would then have been due to his ancestral Westphalian origins and the related familial ties on his father's side. ${ }^{25}$

Little is known concerning his education and early years with the order. In a 1552 memorandum, in which an anonymous author assessed the state of the Teutonic Order in Livonia for Duke Albrecht of Prussia, Jasper is called ein verständiger Herr, der in Kriegshändeln erfahren und nicht ungelehrt ist; denn sonst kann selten einer unter den Herren lesen. ${ }^{26}$ It seems unlikely that any the Order's officials would have been illiterate, given the many administrative tasks that they were burdened with. That Jasper had the benefit of a sound education, however, seems certain nevertheless. It is indisputably evinced by his letters, in which he employs poignant choice of words in an exhaustive display of proficiency in Middle High German. This suggests that he attended school either in Münster or elsewhere in the Holy Roman Empire. It can be presumed that, as a talented young knight brother, he was burdened with important tasks early on. That is why he can be found in 1538 at the significant office of 'Schaffer' (administrative manager) at the Order's castle of Wenden, some fifty kilometres northeast of Riga, where Hermann von Brüggenei, resided as Master of Livonia since 1535. This post was considered a stepping stone to the governance of one of the major commanderies. In 1540 then, he was appointed commander of Marienburg, an Order's castle in the east of presenty-day Latvia. This position brought him the membership of the so-called 'Innere Rat' of the Master: a conclave that regularly convened to discuss the most important administrative matters of the Teutonic order. The members were termed amongst others as 'Ratsgebietiger'.

The rule exercised by a knight brother as commander in Livonia in the sixteenth century is not comparable to the governance of a commandery in one of the administrative districts of the Order within the Holy Roman Empire. In the bailiwick of Utrecht, for example, the commanders of Bunne or Ootmarsum, lorded over some ten or twenty farmsteads centred around a fortified manor with a chapel. Nearly every 'Gebietiger' in Livonia, on the other hand, had an entire province to rule. These Livonian rulers each resided in a castle with its share of knights and domestic personnel, where they served as the landlord of hundreds of dependent peasants who had to perform weekly corvee, pay tenancy monies and fulfil other obligations. The lord also had to preside over legal cases and lead the region's

25 A certain Wilhelm von Münster, for instance, was in 1441 commander of Mülheim, a house of the Teutonic Order in the bailiwick of Westphalia: Ritterbrüder im livländischen Zweig des Deutschen Ordens, ed. L. Fenske, K. Militzer, Köln-Weimar-Wien 1993, no 604.

26 Regesten (as n. 5), no 1545. 
armed forces in times of war. Livonian commanders therefore also had their own household and private administrative personnel.

As a member of a religious community, a Livonian brother was not allowed to have worldly possessions. He had, after all, next to vows of chastity and obedience also made a vow of poverty. Since the Teutonic Order had lost much of its cohesion as a universal spiritual brotherhood in the course of time, the Order's leadership did little to assure whether the vow was abided by. This was already the case by the end of the fifteenth century, both in Prussia and Livonia. Increasingly, the administrative complexes were transferred to the brothers as prebends, to exploit on their own account. This meant that a knight brother who was appointed a commandery or a 'Vogtei' was expected to invest his family fortune in it with the hope for high gains if the property proved profitable. No wonder that nearly every brother who was admitted to the Teutonic Order had the ambition of climbing through the ranks. Whomever was rewarded with the office of commander in due time would be able to acquire the necessary riches, which his kin could then share in. The observation of the Swedish envoy Joachim Burwitz is striking in this light when he remarked in 1555 concerning Livonian 'Gebietiger' that after a career of thirty to fifty years they often bequeathed fortunes of 100,000 to 200,000 marks. ${ }^{27}$ Jasper himself would prove fairly successful in this. Shortly after his flight he calculated his liquid assets, which had been seized by his adversaries, at 30,000 guilders, with four greater and three minor castles, eight 'Gutshoven' and a 'Gesinde' of no less than 2,000 peasants. ${ }^{28}$

The Teutonic Order of the year 1500 thus had become less a religious corporation that defended Christendom against its enemies than a hunting ground for a select number of noble families within the Holy Roman Empire for the acquisition of offices for their younger sons. With the transformation of the Prussian order state into a secular and protestant duchy under Polish sovereignty, this state of affairs ended in 1525 for (East) Prussia. In Livonia, where the Order managed, to a certain degree, to nominally continue exercising its mission of combating the schismatic and thus un-Christian Russians, this trend could continue into the thirties and forties of the sixteenth century. Even some Masters did not hesitate to openly advance their familial interests by providing brothers, cousins and nephews

27 Sind oftmals dreissig, viertzig oder funfzig Jar in den Emptern, schlagen wol Gross Reichtumb zusammen [...] sso lassen sie [...] ein oder zwey hundert tausen marck, cf. S. Neitmann, Von der Grafschaft Mark nach Livland. Ritterbrüder aus Westfalen im livländischen Deutschen Orden, Köln 1993, p. 630.

28 Regesten (as n. 5), no 1826 (Nov. 1556). 
with lucrative posts and functions. ${ }^{29}$ Compounding this was the fact that many of them maintained concubines and managed to provide the children resulting from these affairs with plenty of monies and goods.

We are not informed of any bastards Jasper might have had but he was far from an exception to the rule that high officials of the Order took family members to Livonia. In 1537 there is mention of the presence of Johan van Ewsum's nephew Claes Camphuysen at the Teutonic Order in Livonia. ${ }^{30}$ His father then requests a sizeable sum for Claes from Johan van Ewsum on the basis of Claes' maternal inheritance, amongst others for the purchase of armour. Claes, born c. 1510, was not closely related to Jasper. It is however logical that Johan's father Wigbold, who supervised the children of his sister Ewe, married to Claes Camphuysen's father, would manage to arrange a position within the Order for Claes via Jasper. Jasper's patronage will have been further needed to arrange for Herman van Munster, possibly a descendant from the branch of the family of his uncle Herman, a post as 'Schaffer' of Wenden, where he is present in that office in $1544 .{ }^{31}$ Neither could Johan van Munster, a son of Jasper's brother Roelof, have been appointed as cathedral canon at Riga without Jasper's help..$^{32}$ As for his youngest protégé from his circle of relatives: when Jasper, as land marshall, had to flee headlong to Lithuania in 1556 there turned out to be a Tiarth van Burmannia amongst the young nobles in his entourage. ${ }^{33} \mathrm{He}$ can have been no other than Tjaert, a brother of Johan van Ewsum's second wife Anna. ${ }^{34}$

\section{JaSper as COMMANDER OF MARIENburg}

Because Jasper was the commander of Marienburg, Master Hermann von Brüggenei almost immediately included him in decisions on important matters. For example, Jasper was sent, together with chancellor Lorenz Schlungel and the com-

29 K. Neitmann, Die Spätzeit des Deutschen Ordens in Livland im Spiegel der Alt-Livländischen Güterurkunden, in: Aus der Geschichte Alt-Livlands. Festschrift für Heinz von zur Müblen zum 90. Geburtstag, ed. B. Jähnig, K. Militzer, Münster 2004, pp. 185-238, here 194-195, presents the nepotism of Johann von der Recke, land marshal and later Master of Livonia c. 1540-1550, as a representative case.

30 Hartgerink-Koomans (as n. 21), p. 93.

31 Regesten (as n. 5), no 1283/1 (28.10.1544).

32 Ritterbrüder im livländischen Zweig (as n. 25), p. 460.

33 Regesten (as n. 5), no 1910/1 (Tiarth van Burmannia).

34 Hartgerink-Koomans (as n. 21), p. 192; P. N. Noomen, De genealogie van de Friese adel, volgens Upcke van Burmania: VIII Burmania, te Birdingaterp, te Hitsum en Gratinga, Genealogysk Jierboek 2000, pp. 128-154, here 138. 
mander of Fellin, Johann von der Recke, to the archbishop of Riga in July 1540 to reprimand the archbishop for the atrocities committed by his people in East Livonia against the Russians. ${ }^{35}$ On behalf of the regents of Grand Duke Ivan IV, the Russian envoy had complained about these atrocities to the Master who in turn wished to give the Russians as little cause for displeasure as possible.

It seems that Jasper, as a member of the 'Innere Rat', but also because of his diplomatic talents, was called on by the Master to consult with officials from the Holy Roman Empire, of which the Livonian Confederation had been a part since 1526. This is why Jasper participated in the Imperial Diet at Speyer in April 1544, for instance, when negotiations were held with the Danish king Christian III. ${ }^{36}$ These negotiations resulted in the treaty of Speyer where Christian agreed to maintain peace with the Order, although he made no secret of his aspirations for the Order's territories in Estonia, since these had once belonged to Denmark. Such diplomatic missions gave Jasper the opportunity to travel to the West and visit his brothers and relatives in Groningen and East Frisia in between obligations. ${ }^{37} \mathrm{He}$ would also further his familial interests at those times. For example, he busied himself with arguing for the remunerations that the Van Munster's claimed from the IJssel cities for razing their father's castle Kinkhorst. He also engaged in political concerns connected to the Church. It turns out, for instance, that in or shortly before 1544 Jasper requested his cousin, Johan van Ewsum, to point him in the direction of certain preachers, from whom he hoped to receive new 'articles' concerning baptism and the Holy Communion. ${ }^{38}$ Indubitably this concerns parts of the new church structure that the bishop of Münster, Franz von Waldeck, appointed in 1543, had drafted for the dioceses of Münster, Osnabrück and Minden and which were entirely Lutheran in tone. ${ }^{39}$ The possibility that Jasper acted on behalf of the Master of Livonia, for the benefit of all the Order's territories, cannot be excluded. Hermann von Brüggenei, after all, was held to be a Master who

35 Regesten (as n. 5), nos 1073, 1075/1.

36 Regesten (as n. 5), no 1259/1, in which letter the secretary of Riga makes mention to the archbishop that he had met Jasper van Munster in Speyer.

37 According to a correspondent of the archbishop the commander of Marienburg stayed in Teutschenn Lanndenn in May 1544, cf. Regesten (as n. 5), no 1241.

38 Hartgerink-Koomans (as n. 21), p. 187. Gemeentearchief Groningen, Familiearchief Van Ewsum, no 132: letter d.d. 3-13-1544 from Jasper van Munster to Johan van Ewsum: [...] wolden my ock de beyden artikel van der doepe und aventmale, dar yck J.E. ym yungesten unserenn afschede umb gebeden hebbe, mydt erster thovetlyger botschaft tho verdygen, ock myth dem predicantnen fflyth vorwenden [...].

39 M. Schroor, O. Knottnerus, Verharding en verscherping 1536-1568, in: Geschiedenis van Groningen II. Nieuwe Tijd, ed. M. G. J. Duijvendak e.a., Zwolle 2008, pp. 71-106, here 90. 
strongly promoted the spread of Lutheranism and the building up of evangelical

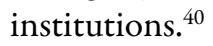

Jasper visited the West again between the years of 1545 and 1547. As shown by an extensive report on the events in the Netherlands, which Archbishop Wilhelm included in a letter sent to his brother Albrecht, Jasper was present at the inauguration of Queen Mary of Hungary, sister to Emperor Charles V, as governess of the Netherlands in 1545. At that occasion the city of Groningen donated 100,000 Groschen and all manner of commodities in kind to the queen. The informer thought it noteworthy to mention that Jasper, present at the court, had gained widespread attention with his gift of two live salmons in an aquarium. ${ }^{41}$ In 1547 Jasper travelled to the West via Poland, presumably to support the diplomat and councillor of Master Herman von Brüggenei, Philipp von der Brüggen, who had been the Order's deputation to the emperor. ${ }^{42}$

\section{The Russian THREAT IN THE PERIOD OF 1550-1551}

In the following years Jasper appears to have been actively recruiting mercenaries in the Netherlands and Northwest Germany for possible actions in Livonia against the Russians on behalf of Brüggenei and Johann von der Recke, Brüggenei’s successor after 1549. Jasper' brother Jurgen played a major role as a mercenary leader, next to Wilken Steding, bailiff at Cloppenburg and brother to Heinrich Steding, a member of the Order. ${ }^{43}$ In early January, 1548, Jurgen wrote to Johan van Ewsum to say that he and Wilken Steding were mustering troops for denn Duesschenn her meistern, although he did not expect the venture to proceed, because he concer-

40 In the opinion of Wittram (as n. 1), pp. 64-65, all Livonian Masters after Plettenberg sympathized with Lutheranism, however without drawing political conclusions from their inclination - which is quite understandable since a formal acceptance of Protestantism would have meant the dissolution of the Order. Master Hermann von Brüggenei though, did not think the building up of an evangelical church organization would endanger the continuity of the Order: J. Kreem, Der Deutsche Orden und die Reformation in Livland, in: The Military Orders and the Reformation. Choices, State building, and the Weight of Tradition. Papers of the Utrecht Conference, 30 September - 2 October 2004, ed. J. A. Mol e.a., Hilversum 2006, pp. 43-58, here 52.

41 Regesten (as n. 5), no 1315/3. On the visit of Mary of Hungary to Groningen see J. Kerkhoff, Maria van Hongarije en haar hof (1550-1558), Hilversum 2008, p. 222; and W. B. S. Boeles, Het bezoek van de landvoogdes Maria aan de Noord-Nederlandsche gewesten, Bijdragen tot de Geschied-, en Oudheidkunde van de provincie Groningen 2 (1865), pp. 207-246, here 207; Regesten (as n. 5), no 1315/3.

42 Regesten (as n. 5), no 1426.

43 He was 'Vogt' of Kandau at that time: Ritterbrüder im livländischen Zweig (as n. 25), no 834. 
ned himself first with the preparations for a campaign on behalf of the bishop of Münster. ${ }^{44}$ Two years later, in the summer of 1550 , with Johann von der Recke as Master of Livonia and tensions with Moscow rising high, both men were to be found back in Livonia. ${ }^{45}$ This was to inspect the borderlands and to prepare to recruit 'Landsknechte' willing to hire themselves out for war against the Russians.

The Muscovite threat had been felt strongly in Livonia for some years. After the 1503 armistice, renewed in 1509 and 1531, Grand Duke Vasili III of Moscow had left Livonia aside. With his overwhelming number of men-at-arms he preferred to focus on Lithuania - conquering Smolensk and other fortifications. He was furthermore distracted by Tatars in the Southeast every now and then. Nevertheless, the armistice between Livonia and Muscovy was brittle and uneasy. There were continuing conflicts upsetting the balance between the two powers. Border skirmishes were common and conflicts arose over toll exemptions which the Russians demanded for their merchants. The threat of Russian invasion intensified when Vasili's son Ivan IV, born 1530, who had himself crowned czar in 1547 , personally took charge of the expansionary politics of his principality. A first excuse to take an aggressive stance against Livonia was the Confederation's refusal to provide passage to gunsmiths, munitions and other wares that Ivan had ordered in England and Saxony for his war efforts. Ivan's self-conscious action was exemplified, for instance, in the manner in which he received the Livonian legation that came to Moscow in the summer of 1550. This legation came to discuss the continuation of the armistice that would expire in 1551, but Ivan opened this discussion with a round of insults ${ }^{46}$, and then sent the legation home with a list of intractable demands. The only reprieve was that Ivan gave the Livonians a full year to give in to his demands.

That Jurgen van Munster and Wilken Steding were received at Wenden by Master Johann von der Recke, Jasper and other prominent 'Gebietiger', has to be connected with the expectation that negotiations with Moscow would fail. Anticipating this, a number of ships had already arrived in Riga from Lübeck with 500 mercenaries and three new knight brethren, all of whom had then to be dispersed among the Order's castles. Meanwhile, Steding and Munster inspected the borders on horseback to ascertain all that would be needed for defending the territory. By autumn 1550, full-scale mobilization was not yet necessary, as the action of reinforcing the territories had bought the Livonians some time. Both military

\footnotetext{
44 Gemeentearchief Groningen, Familiearchief Van Ewsum, no 32, letter of 1548

45 Regesten (as n. 5), no 1514/2 (this is a text from a later date, in which the author looks back at events of 1551).

46 Regesten (as n. 5), no 1516 (4. 12. 1551).
} 
enterprisers then returned back to the West. There they continued recruiting mercenaries for use in Livonia the next year, according to the communiqués that Archbishop Wilhelm sent to his brother Albrecht. ${ }^{47}$

Halfway through February 1551, a significant Russian legation with 42 horses arrived at Wenden for a more thorough discussion of the demands made earlier. ${ }^{48}$ The Master of Livonia and the other members of the Confederation were inclined to comply. They did indeed expand the freedom of trade for Russian merchants and offered the czar reparations for the confiscated trading goods. And thus the envoy from Moscow could visit the Master, the archbishop of Riga (in Ronneburg) and the bishop of Dorpat in turn to have them affirm the extension of the treaty for the period of a year and - if certain demands were met - a further five years. The envoy did, by the way, complain to the archbishop about the poor treatment afforded to him at Wenden and the Marienburg (i.e. with Jasper). ${ }^{49}$

The Order's reaction shows clearly that Master Von der Recke and his 'Ratsgebietiger' did not trust the czar to leave Livonia truly alone under these conditions. On the contrary, they called for their commanders and order's vassals to make their men ready. ${ }^{50}$ Furthermore, the supply of mercenaries, so long in planning, was confirmed, and would arrive, as soon the overseas route was free from ice. In a communiqué dated 12 April there is mention of 5,000 'Landsknechte' and 3,000 cavalry en route from the West to Livonia. ${ }^{51}$ During this tumult, Master Johann von der Recke passed away on 18 May. He was succeeded by the seventy year old land marshal Heinrich von Galen, who subsequently promoted Jasper van Munster to land marshal. This made it Jasper's duty to take supreme command over the available forces. Shortly after his appointment, all lords and commanders united under his banner in the borderlands, and with all their men at arms, were ordered to be equipped and armed for a possible action against the Russians. ${ }^{52}$

Extant publications have paid little attention to this mobilization, possibly because contemporary chronicles make no mention of it..$^{53}$ Yet the threat of Russian invasion seems to have been genuine. According to a rapport by an in-

47 Regesten (as n. 5), nos 1506 (21. 10. 1550); 1510 (19. 12. 1550).

48 Regesten (as n. 5), no 1514/1 (21.3.1551).

49 Regesten (as n. 5), no 1516 (4. 12.1551).

50 Regesten (as n. 5), no 1517/5 (4.12.1551).

51 Regesten (as n. 5), no 1514/3. A part of these mercenaries were passing through Lochstedt at that time, not far from Königsberg in East Prussia.

52 Regesten (as n. 5), no 1544.

53 N. Angermann, Studien zur Livlandpolitik Ivan Groznyjs, Marburg 1972, pp. 11-12; K. Rasmussen, Die livländische Krise 1554-1561, Kopenhagen 1973, pp. 20-21, make mention of negotiations, but they keep silent on the military pressure from the side of the czar. Angermann though, does notice that Master Johann von der Recke sent an urgent request for help to the 
formant to Duke Albrecht from 1552, the czar moved a significant armed force, comprising of 100,000 Muscovites plus an additional 18,000 Tatars, to Livonia. ${ }^{54}$ These would have reached the border around St. Martin's Day (the $11^{\text {th }}$ of November). Against that, the Confederation could bring no more than 7,000 German men-at-arms to complement their own, limited, forces: 3,000 at the Order's expense, 2,000 on behalf of the archbishopric of Riga and 2,000 from the cities of Riga, Dorpat (Tartu) and Reval (Tallinn). The informant neglects to mention whether these mercenaries had been actually hired - although this can be assumed based on the aforementioned messages. The Russian incursion did not come to pass, in the end, for two reasons. The first was a lethal epidemic ('das gewaltige Sterben') that autumn in Harrien and Wierland which apparently frightened the Russians. Secondly, the would-be invaders were hampered by the mild and fickle winter which prohibited progression because of mud. Given the number of warriors, the anonymous informant concludes that if God had not prevented the invasion, the land would have been helplessly lost.

\section{The anti-Russian And anti-Polish parties in Livonia Until 1555}

That his troops returned home without results did nothing to dissuade czar Ivan from keeping up pressure on Livonia. Neither did it mean that the new Master was any less fearful of the Russian archenemy. In an apologia drafted of January 1558, Jasper van Munster tells how a year after his appointment Heinrich von Galen sent his interpreter, Johan Anrep, to Moscow to discuss the continuation of the peace terms. ${ }^{55}$ Anrep was not even received by Ivan. He reportedly was laughed at by the czar's compatriots with the comment that the czar was willing to send him an escort of 80,000 Tatars. This mocking and audacious tone was inspired by Ivan IV's conquest of Kazan in the spring of 1552, with which he had subjugated and incorporated a part of the Tatars, which also meant that he was now free to expand his empire to the north and west. By not admitting new legations from the master and the Livonian Confederation into Moscow and by preventing them from travelling further than Novgorod and Pskov, Ivan was displaying his power to increase his demands.

emperor around the turn of the year 1550/1551 which expresses "Furcht vor einem Eroberungskrieg Moskaus".

54 Regesten (as n. 5), no 1545.

55 Regesten (as n. 5), no 2136. 
In this way, the treaty expired by autumn 1552 , without being extended in any form. ${ }^{56}$ According to Jasper van Munster, all wise 'Gebietiger' and councillors pleaded from then on to Master Heinrich von Galen, in all meetings and conferences, within the Order and beyond, to enter into sustainable alliances with Poland and Sweden and to seek support within the Holy Roman Empire. Amongst them were the aforementioned Philipp von der Brüggen and dr. Johan van Buckhorst, from Overijssel, the Master's new advisor. ${ }^{57}$ Initially Galen acquiesced by sending diplomats and confidants to the aforementioned parties. There were, however, dissenting voices, increasingly being heard over time. Opposition came from the side of (1) a number of Order officials in the south, who were often in conflict with the potentates of Lithuania; (2) the Livonian suffragan bishops, including the bishop of Dorpat (Tartu), who was of the opinion that one could better accede to the czar; and (3) the cities of Riga and Reval (Talinn), as well as other parties, who maintained a deep distrust of Archbishop Wilhelm of Brandenburg-Ansbach on account of his alliance with Poland and the duke of East Prussia.

The latter faction deserves some explanation. Wilhelm of Brandenburg was, as mentioned, a brother of the former Grand Master of the Teutonic Order, who had transformed the Order state in East Prussia into a secular duchy in 1525 under Polish sovereignty. That transformation obviously did not sit well with the remaining parts of the Teutonic Order, of which the Livonian branch was in close geographical proximity. There was also a certain threat emanating from Albrecht's secularization politics. It was imaginable, after all, that ambitious sons of princes might settle in one of the ecclesiastical states in Livonia and try to follow Albrecht's example.

The Estates of Livonia did, however, consider the establishment of a secular state at an earlier stage. In 1526, at the Diet, they offered the highly-regarded Master Wolter von Plettenberg the chance to secularize the Order state. He, however, was disheartened because he considered the Order too weak and the Confederation as a whole too heterogeneous to continue as a strong dynastic state. $\mathrm{He}$ realized furthermore that the Order's membership, comprised as it was of brothers coming from the lower nobility, would not be pro-dynastic in the least. The corporation traditionally had no dynast's sons in its midst and neither did it want to. For the same reason it would not allow one of its members to raise himself above

56 "Die vertraglichen Verhältnisse zwischen 1552 und 1554 scheinen in der Luft geschwebt zu haben", cf. Rasmussen (as n. 53), p. 21.

57 Jasper van Munster notifies that in this context Heinrich von Galen delegated amongst others Rupert von Gilsen to the king of Sweden, and Gotthard Kettler with the chancellor (Bötticher) to the Hanse towns, the archbishop of Cologne, the bishop of Münster and the duke of Cleves (Kleve) to ask them for support. 
the others as a monarch only to hamper the development and ambitions of others. Plettenberg's successors Brüggenei, Recke and Galen could not broach the subject of a new policy for that reason alone. They simply missed the power and influence of neighbouring rulers to force an Albrecht-like solution.

Meanwhile there was one party that wanted to transform Livonia, or at least a part of it, into a protestant principality. That was the archbishop of Riga, Margrave Wilhelm of Brandenburg-Ansbach, who was kin to nearly all Middle-European dynasties. He could call the Polish king Sigismund II Augustus 'cousin' and count on his patronage. His election, first as coadjutor (delegate with the right to succession) of the incumbent archbishop in 1529, and his subsequent appointment to prelate in 1529, were largely the work of Duke Albrecht. Wilhelm, who can be said to have lacked the energy, determination and vision of his brother, first tried to establish a Lutheran church organization, and put everything to work to modernize his archdiocese in the political sense. He ran into fierce resistance in his attempts, not just from conservative forces within the Order but also from the city of Riga and his suffragan bishops who feared the increase of his archiepiscopal power. In 1546 the Diet at Wolmar decided for that reason that the assent of the Estates would be needed for the appointment of any coadjutor, both for the archdiocese as well as for the Teutonic Order. Meanwhile, the other parties closely watched Wilhelm's affairs.

One of the most important representatives of the anti-archiepiscopal and certainly also anti-Polish and anti-Prussian party was the former commander of Dünaburg, Wilhelm von Fürstenberg. He was known to be an ironside who had a tendency to solve conflicts with Lithuanian nobles in the borderlands by force of arms, to the detriment of many a poor farmer. According to Jasper, he had been released from his post once by Hermann von Brüggenei for his violent methods. ${ }^{58}$ Nevertheless he was also valued as a decisive administrator and was counted next to Jasper as a candidate for the office of Master. Jasper's confidant Johann von Hoete, house commander of Mariënburg, informs us in his personal apologia that Heinrich von Galen first offered the position of land marshal to Fürstenberg, but he had declined the offer to expand the Dünaburg. ${ }^{59}$

As 'Ratsgebietiger', Fürstenberg, together with Christoph Neuhof, commander of Goldingen, managed to increase his influence on the old Master. This can also be seen in 1554, when Fürstenberg was promoted to the commandery of the wealthy Fellin, at the expense of the incumbent commander Heinrich von

58 Jasper kwalifies him as a bloodthirsty “aufrürerischer, tyrannischer Mensch”, cf. Regesten (as n. 5), no 2151.

59 Regesten (as n. 5), no 2137. 
Thülen. ${ }^{60}$ Fürstenberg may be seen as the leader of the anti-Polish, anti-Prussian and therefore anti-archiepiscopal party within the Livonian branch of the Teutonic Order. In 1554, as new negotiations with the czar aproached, he and bishop Hermann II of Dorpat pleaded to be more willing to meet the czar's demands.

Much can be said of the fifteen year peace treaty that was made with Russia in 1554 , but the theme of this paper does not permit extensive discussion. ${ }^{61}$ Whatever review of it is consulted, however, be it from that time period itself, the nineteenth century or the past few decades, everyone acknowledges that it was a completely one-sided affair. The chief issue was that Livonia was ordered to never enter into an alliance with Poland; the Confederation was to remain alone in the event of a war between Moscow and Poland. Maybe the polonophobic Fürstenberg was satisfied with that, but it meant political isolation for Livonia. This was shown soon after, when King Gustav of Sweden decided to solve a trade dispute with military might only to discover that he could not rely on support from Livonia, contrary to what the Master's envoy had led him to believe. ${ }^{62}$ Much more objectionable was the stipulation that the Russian claims to the payment of tribute from the diocese of Dorpat had to be upheld. The interpretation of the nature and amount of this tithe had been stretched by the Russians more and more over the course of the negotiations. ${ }^{63}$ Dorpat was not only to settle the payments from the preceding years and as well as those to come, which totalled one Rigan mark

60 Compare Ritterbrüder im livländischen Zweig (as n. 21), nos 277, 651, where the data for both men on the commandership of Fellin do not entirely match with one another. On the removal of Thülen see Regesten (as n. 5), no 2137.

61 For a more detailed analysis of the treaty clauses see the studies of Angermann (as n. 53), pp. 1-24; and Rasmussen (as n. 53), pp. 19-27. Compare the recent introduction of Hartmann in his volume on the years $1551-1557$ (as n. 5), p. xi.

62 Regesten (as n. 5), no 1752 (1. 1. 1556). In this letter from Archbishop Wilhelm to King Sigismund II of Poland it is said that delegates of King Gustav of Sweden had explained to the archbishop that their king had made a firm stand against Ivan IV in the opinion that he would get support from Livonia since the Livonian Master had some time before sought to form an alliance with him against the Russians (though this had not materialized); Gustav then had declared war upon Moscow without knowing that Livonia in the meanwhile had concluded a humiliating peace with Ivan IV. He therefore asks the archbishop to do his utmost that Livonia will break this peace and give support to Sweden.

63 A. Selart, Der 'Dorpater Zins' und die Dorpat-Pleskauer Beziehungen im Mittelalter, in: Aus der Geschichte Alt-Livlands. Festschrift für Heinz von zur Müblen zum 90. Geburtstag, ed. B. Jähnig, K. Militzer, Münster 2004, pp. 11-38, here 36-37. According to Selart, it is very likely that these tax payments went back on certain rights that the city of Pskow had exerted in the thirteenth and fourteenth centuries. This tradition however, was clearly elaborated and stretched by the Moscovite negotiators to underpin Ivan's thesis that this part of Livonia was a hereditary Russian domain, the German inhabitants of which had only acquired colonization rights against the regular payment of taxes to the grand duke. 
per person, but they were also tasked with paying dues equal to a half century of annual tithes. The diocese was given three years to collect the demanded sum. And if the diocese could not raise the money, the czar was allowed to charge all of Livonia for the payments. Furthermore, Riga, Reval and other cities had to promise free trade to merchants from Novgorod and Pskov, whether these merchants were Livonians or foreigners.

All of this made the treaty into a ticking time bomb that czar Ivan IV could detonate at any time after 1557. Jasper wrote that he resisted the treaty since the beginning. He even considered feigning illness to avoid attending the ratification ceremony, where he was to kiss the cross when the Muscovite legation arrived at Wenden as a homage and as a mark to seal the peace treaty. In his own words, Jasper and several other council members and envoys tried time and again to persuade the Master and other members of the Confederation to reach out to Poland. This was for the sake of the preservation of their old liberties. It is the main theme in almost every letter dealing with his justifications for his political stance and behaviour: the Order will do better allying with the Christian king of Poland and risk open war than to join with an unchristian tyrant. After all, it was the Order's mission als Vormauer der Christenheit gegen die Unchristen zu dienen ${ }^{64} \mathrm{He}$ also considered the Russians insistently to be unchristian rather than schismatic.

\section{THE COADJUTOR ISSUE}

Meanwhile, Archbishop Wilhelm pressed in the opposite direction. Since he had barely, if at all, made any progress with the secularization of his archdiocese for fifteen years, he and his brother tried to have another dynast's son appointed as coadjutor. This was indended to both reinforce the weak power base of the archdiocese of Riga, as well as to further their familial interests and draw Livonia into the Prussian sphere of influence. Their choice fell on Christoph, a younger brother of Duke Johann Albrecht of Mecklenburg, who in turn was also a cousin to King Sigismund II of Poland and a son-in-law to Duke Albrecht. As stadtholder with the right to succession, this Christoph would be able to take over the administration when the circumstances were favourable. Such a settlement was also in the interest of the kings of Poland and Denmark as protectors of the archdiocese. Account

64 Especially his apologia is explicit about this as it states that ever since 1554 Livonia is without peace having to fear every day it will be invaded: Caspar von Münster's, Landmarschall des D.O. in Livland, Verteidigungsschrift, Mittheilungen aus dem Gebiete der Geschichte Liv-, Esth-, und Kurlands 10 (1861), pp. 143-160, here 146. 
had to be taken, however, of the conditions that the Diet of Wolmar in 1546 had stipulated for the election and confirmation of coadjutors. The most prominent stipulation was that the new incumbents were prohibited from transforming their archdiocese or Order territory into a secular principality or enter into negotiations with the Polish king. Wilhelm himself was a signatory to this precondition. He was of the opinion, however, that he could circumvent this clause by stating that it had not been ratified by the emperor and therefore lacked legal grounds. The plan took shape in the course of 1554 and 1555 through discussions with several dynasts and the cathedral chapter of Riga.

Further polarization and partisanship developed therefore within the Order and between the Order and other members of the Livonian Confederation. In the correspondence between Archbishop Wilhelm and Duke Albrecht this tension is apparent too. There are communiqués about the hiring of 'Landsknechte' and the mobilization of Order's troops to ambush him and his people. Informants provided intelligence about who was actually setting the course for the Order and how many soldiers the various parties could bring to bear with or against each other. ${ }^{65}$

In this climate, Wilhelm von Fürstenberg and Jasper van Munster seem to have drifted further and further apart, with the result that Jasper increasingly sided, or had to side, with the archbishop. Jasper's envisioned union with the Polish king also brought rapprochement from the brothers Brandenburg-Ansbach. By their relation to Sigismund II such an alliance could be made all the stronger. Jasper saw himself as the most suitable candidate for the Master's office, but he knew he had to take Fürstenberg and others into account. At the start of 1555, it was not yet clear who would be the winner. The archbishop mentioned to his brother on 19 January that after the current Master's death a "rare play for power" would take place: the commanders of Fellin (Fürstenberg) and Goldingen (Neuhoff) both aspired to be Master, and had to remove the land marshal from the equation. ${ }^{66}$ A spokesperson had let the archbishop know that Jasper in turn sought to prevent this state of affairs with the help of Wilhelm; since the land marshal had an interest in maintaining cordial relations. From this, it can be deduced that Jasper by then had not established direct contact with the archbishop.

Before the autumn of 1555, there is no allusion to contact with Jasper in the correspondence between the two brothers. Yet it seems that Jasper had been in close conference with the archbishop since the spring or summer of that year. In a later letter from Wilhelm to his brother, dated 11 May, 1556, as well as in a later piece of writing from Duke Albrecht to Sigismund II, dated 1 June, the archbishop

65 For instance in Regesten (as n. 5), no 1711 (undated, 1555/1556).

66 Regesten (as n. 5), no 1660/1. 
requests for support for the land marshal (who had fled already by that date) since the latter had helped him last year in preventing an ambush by the Order of the episcopal castle Kokenhusen: he would then have forbidden any of his men to saddle a horse. ${ }^{67}$ Jasper, in a later apologia, further points to attempts by the Master, supported by Fürstenberg, to have the stronghold of Dünamünde, close to Riga, taken from him by one of his followers for later use in the coming battle against the archbishop; against which Jasper had naturally resisted since Dünamünde fell under his command.$^{68}$ In other words, by 1555 Jasper had made it impossible for Fürstenberg and his compatriots to force Wilhelm with military pressure to meet their demands by concerning the coadjutor issue. This will have taken place in late August or early September, shortly after the land marshal, with Gotthard Kettler (who had succeeded Fürstenberg as commander of Dünaburg) had approached the archbishop with a complaint concerning aggressive behaviour from Wilhelm's men. ${ }^{69}$ Only on 26 September there is mention of a private meeting between Jasper and the archbishop, but this may very well have taken place after the ambush had been thwarted. ${ }^{70}$

Tensions rose higher when on 27 November, 1555, Christoph of Mecklenburg, the coadjutor to-be of the Rigan metropolitan, arrived after a stopover in Königsberg at the archiepiscopal castle of Kokenhusen. In response, Wilhelm called the cathedral chapter and the Estates of the archdiocese to session to have the candidate appointed to coadjutor. ${ }^{71}$ This action by Wilhelm must have pro-

67 Regesten (as n. 5), no 1826 (Archbishop Wilhelm to Duke Albrecht (11. 5. 1556); Documenta ex Archivo Regiomontano ad Poloniam spectantia (as n. 6), vol. 34, no 4364, pp. 106-107: letter from Duke Albrecht to King Sigismund II, in which he explains that the Order has conquered the castles of the land marshal and routed the latter because he would have resisted the attempts of the Order and its Master, incited by the new coadjutor (Fürstenberg), to besiege the archbishop at his castle of Kokenhusen: [...] quod ordinis conatus et machinationes iniustas elapso tempore, quibus statuerant dominum archiepiscopum in arce Kockenhausen obsidendum et opprimendum, noluit approbare neque consentire, ut novus coadiutor magistro adderetur.

68 Regesten (as n. 5), no 2135 (at the end of 1557 or the beginning of 1558). The Master claimed rights on the castle of Dünamünde since he had strengthened and reinforced it by his own means during the period he administrated it as land marshal himself.

69 Regesten (as n. 5), no 1697 (17.8. 1555).

70 Regesten (as n. 5), no 1705. This concerns a proposal for a date appointment, in reply to a request, dated September 26, of the land marshal to meet one another for consultation.

71 Even the chronicler Bartholomäus Grefenthal, who was well-disposed to Archbishop Wilhelm, considers this to be a "point of no return": Auf diese postulation des neuen Coadjutoria erbub sich der strcitt undt innerliche empörung zwischen den Teuzschen orden undt den Erzbischof, welche diesen landen der endliche Verderb gewesen [...], cf. Bartholomäus Grefenthal's livländischen Chronik, ed. F. G. Bunge, in: Monumenta Livoniae Antiquae, vol. V, Riga 1847, pp. 1-123, here 118-119. 
voked the opposing forces within the Confederation. The Master and the other Estates of Livonia were unwilling to concede, and let this be known when the Polish king sent a legation under the leadership of Caspar Luntzki to Livonia to keep up the pressure on behalf of the coadjutor plot. The envoy was received on 12 January, 1556 in a 'boorish' fashion by the Master. He was refused the main seat at the dining table and was refused permission to visit the toilet during the meal. ${ }^{72}$ Furthermore, it was made clear to the envoy by the Master without ambiguity that there was nothing to negotiate, for the matter of whether and how the coadjutor would be acceptable to the Estates of Livonia would be decided at the Diet of Wolmar in February or March of 1556.

Meanwhile the Master, instigated by Fürstenberg, had made preparations for military action against the archdiocese. At the end of the year, he organized a secret conclave of a number of loyal 'Ratsgebietiger' and important representatives of the estates in a general meeting at Wenden, for which the archbishop had naturally not been invited. Nor did Jasper and his supporters receive invitations. ${ }^{73}$ At this general meeting or 'Herrentag' it was decided to send the commander of Dünaburg, Gotthard Kettler, to Northwest Germany and the Netherlands incognito to recruit mercenaries to be employed against the archdiocese. In the early morning of 27 January, without informing his servants, Kettler departed, with four sleds to a Lithuanian port, to sail from there to Lübeck. With the comment "that it is better to make the first move than to be a victim of it" the chronicle by Salomon Henning written in the 1590s beautifully encapsulates the reasoning of this action. ${ }^{74}$ Kettler's stealthy departure did not go unnoticed, however, and an informant alerted Archbishop Wilhelm on January 9.

72 Regesten (as n. 5), no 1755 (report of a correspondent to Duke Albrecht, 18. 1. 1556).

73 I could not find the exact date. The seventeenth-century Swedish chronicler Thomas Hiärn places the event in the new year. Probably the meeting took place at some day in December, between November 27 and January 1: Thomas Hiärn, Ehst-, Lyf-und Lettländische Geschichte, ed. E. Napiersky, in: Monumenta Livoniae Antiquae, vol. I, Riga 1835, p. 206.

74 Salomon Henning's chronicle of Courland and Livonia, ed. and transl. C. Smith, W. Urban, W. Jones, Wisconsin 1992, sub anno 1556. It strikes the eye that Johannes Renner, who usually gives lots of details, is very vague and imprecise in his dating here. Contrary to Salomon Henning he does not make mention of the secret meeting at Wenden and he fails to distinguish between the events in the autumn of 1555 and those in the first months of 1556 . In this way, he can place Kettler's mission to Germany after the letters of the archbishop to Duke Albrecht from April 1556, containing a proposal to intervene militarily, had got around. For him, the land marshal and the archbishop were the evildoers: they would, when only Jasper had succeeded in becoming Master after the death of Galen, split up Livonia in two principalities: [...] konden alszdan ore vorhebbende practiken wercklicken vortstellen, die lande tho partiern und delende. In Renner's vision, Fürstenberg would thus have acted only in reaction to the striving 
It is furthermore of importance that at that same secret meeting at Wenden, Fürstenberg was promised the future office of Master, at least according to Archbishop Wilhelm, as he learned of it second-hand. ${ }^{75}$ In other words: Fürstenberg had already pocketed his promotion to coadjutor for the Master before he had been formally elected as 'Ratsgebietiger' and sworn in at the Diet. Jasper's confidant Johann von Hoete, former house commander of Marienburg, referred to this in his early 1558 apologia, when he wrote that children in the streets knew of Fürstenberg's promotion before the land marshal did, and that Fürstenberg was referred to abroad as coadjutor long before his election. ${ }^{76}$ All of this indicates how the leadership of the Confederation was now in the hands of Fürstenberg. Although no written records remain, it can be presumed that he immediately took precautionary action against any possible resistance by Jasper, amongst others, by courting the most important dignitaries of the Order. The celerity of the actions against the land marshal, his men and his castle in the name of the Master after the Diet speaks volumes.

\section{The Diet, the conspiracy and Jasper's flight to Kaunas}

The meeting of the Estates of Livonia at Wolmar opened on 1 March 1556 with the coadjutor issue for the archdiocese of Riga as its foremost point of discussion. Archbishop Wilhelm was absent but was represented by emissaries. Before the meeting took place, Wilhelm wrote his brother in Königsberg and described the event as a sham fight. ${ }^{77} \mathrm{He}$ was not wrong, as all the parties involved had already entrenched themselves and would prove utterly unwilling to make concessions. Jasper van Munster does not seem to have realized this beforehand. In fact, encouraged by the Master, Jasper tried to take advantage of the circumstances to explain once again and at length, his position with regards to the Russian threat. He decried the political maneouverings of the Confederation's leadership for leading to a disadvantageous peace with Moscow while neglecting the relations with Poland and Sweden, Jasper also found fault in the tardiness of the communication of the treaty, since the archbishop only learned about this peace some days after the fact, and had little choice then but to concede to the treaty against his will. According to Jasper, the feuds with the archbishop had to be reconciled as soon as possible. Unity and solidarity were what was needed, not just with in Livonia, but also between Livonia and its neighbouring Christian states, so

for power of Jasper and Wilhelm: Johannes Renner, Livländische Historien, 1556-1561, ed. P. Karstedt, Lübeck 1953, pp. 8-10.

75 Regesten (as n. 5), no 1784 (17.2. 1556), letter from Archbishop Wilhelm to Duke Albrecht).

76 Regesten (as n. 5), no 2137 (1558, undated).

77 Regesten (as n. 5), no 1784 (17.2. 1556). 
that they could resist the 'unchristian enemy' from Moscow. ${ }^{78}$ In his view, the border conflicts with Poland-Lithuania, over which the tensions rose so high in the south of Livonia, could be resolved without much effort. First and foremost, however, the czar's power was Jasper's concern. According to Jasper, the Muscovite conquest of Smolensk, belonging as it did to Poland-Lithuania, and also recent annexations of Swedish territories, demonstrated Moscow had reached too far. Jasper pleaded in this context for entering into a union with the king of Poland.

At Wolmar, Jasper handed over a written statement with these and other considerations to Master Heinrich von Galen, the six most prominent commanders of the Order, four council members from Harrien and Wierland, and the syndic of Reval, with the intention of discussing these points in a private session after the public reading of the text. The Order's vice-chancellor, however, supposedly hid the text away after reading two and a half pages, only to then leave the room silently. The next day and in days to follow, no mention was made of the text. This alone shows that the land marshal failed to procure support for the course of action he proposed. But, instead Jasper was vilified as a warmonger, firebrand and enemy to the Confederation.

Worse yet for Jasper was that the intended election of Fürstenberg to coadjutor finally came to pass at the close of the meeting, on 15 March. According to Jasper the election was held after all topics had been discussed and the servants were already outside readying the horses. ${ }^{79}$ The choice was supposedly made by the six aforementioned 'Ratsgebietiger', to wit the commanders and 'Vögte' of Reval, Jerwen, Goldingen, Marienburg, Soneburg and Kandau. Those who opposed Furstenberg's election (including Philipp Schall von Bell, commander of Marienburg) were not allowed to demonstrate their opposition beyong the walls of the chamber. Jasper does not seem to have been happy with the results. His secretary Johann von Hoete noted in his personal apologia that the land marshal was only notified of the election after gefasstem Beschluss. ${ }^{80}$

The reason Jasper considered the election illegitimate was twofold. Firstly, it had been made without decent consultation beforehand. Secondly, in opting for Fürstenberg the land marshal had been passed over as the traditional choice for succeeding the Master; Galen and Recke had been land marshal themselves before being named Master. Jasper challenged the idea that his pro-Polish sentiments had shown him to be unworthy to be Master. If anyone did not want him to be Master for these reasons, then surely Fürstenberg as well was not fit as a candidate either, since Furstenberg

\footnotetext{
78 See Jasper's justification in a letter to Archbishop Wilhelm d. d. 6. 4. 1556, cf. Regesten (as n. 5), no 1813.

79 Regesten (as n. 5), no 1910/5 (7. 5. 1556), letter to Heinrich von Galen, 'Vogt' of Bauske).

80 Regesten (as n. 5), no 2137. When Jasper afterwards withheld his assent, Bernt von Schmerten, 'Vogt' of Jerwen, would have termed him disobedient .
} 
had notoriously poor relations with Livonia's southern neighbours. Jasper was of the opinion that the position should have fallen on a younger individual, such as the commander of the Dünaburg, Gotthard Kettler, or the 'Vogt' of Wesenberg, the Limburgian Gerhard Huyn van Amstenraide. To voice his opposition, Jasper withheld his approval of the election, lending further justification for the election's illegitimacy. Jasper's opposition to the election process itself in turn meant that he did not acknowledge Fürstenberg as coadjutor.

Jasper and Archbishop Wilhelm thus both had been moved into a difficult position. Jasper was furious over the entire course of affairs and decided to struggle against it with his life and livelihood. ${ }^{81}$ There seemed to be only one option left for him and the archbishop if they were to reverse what had take place. This was to call for the support of both the Polish king and Duke Albrecht and raise interest with either of them to pose a common military threat against the already mobilizing ${ }^{82}$ Order and Estates. Together Jasper and the archbishop could call upon the support of a significant number of castles and men. The idea was that by combining forces, and with added pressure from other allies, Jasper and the archbishop could easily sway their opponents within the Confederation and have them relent their support for the election of Furstenberg. If that plan succeeded, Jasper planned for the king of Poland to be accepted as hereditary lord protector of the Teutonic Order, after which the aforementioned king was to preside over an honest election for the office of Master. Jasper himself would take care that in the meantime, that the Order's commanders would come to obey him, on the basis of the fact that as land marshal he had been affirmed by the emperor and the Deutschmeister. Either at the end of March or the start of April all these plans were put to paper in cypher and sent to Duke Albrecht and King Sigismund. Jasper does not seem to have dealt with the correspondence to the Polish king himself. He did have his confidant Johann von Hoete expound his ideas to Archbishop Wilhelm. There is, however, a letter from Jasper to Duke Albrecht, dated 6 April. Jasper hoped to move quickly when he discovered that the Master (or better, coadjutor Fürstenberg) had already withdrawn staff from his castles Dünamünde, Ascheraden and Segewold.

According to Wilhelms calculations the land marshal possessed eight strong castles including the Dünamünde, which at the mouth of the Dvina controlled all

81 The most important sources for the reactions of both men are the letters of April 6 (Jasper to Duke Albrecht) and April 8 (Archbishop Wilhelm to Duke Albrecht), cf. Regesten (as n. 5), nos $1813,1814$.

82 Both Wilhelm and Jasper (the latter possibly via his brother Jurgen) were well acquainted with Kettler's mission to gather mercenaries for putting pressure on the archbishop. 
shipping traffic to Riga with its cannonry, and nine manors. ${ }^{83}$ To his own forces Jasper could add 200 mounted soldiers from these manors and he could procure a further 300 knights from elsewhere. This ought to have been sufficient to deal with the Master's forces. If Duke Albrecht could deal with the men-at-arms of the commander of Goldingen, and the Polish king could bind the commander of Fellin, the Order's force would be largely neutralized. If naval forces could be brought into play, with ships crossing at Riga and Reval, closing off Pernau and performing raids at several coastal locations, the cities and the nobility of Harrien and Wierland would also be taken care of if they wanted to offer resistance. This last part of the plan had been put to be paper by Archbishop Wilhelm before (without Jasper knowing it), in a letter of a confidant to Duke Albrecht from the summer of $1554 .{ }^{84}$

It would prove to be a last major setback for Archbishop Wilhelm and Jasper that a letter detailing some of these plans was intercepted and deciphered. The text of the intercepted letter itself cannot be found in an official source edition. If, however, the letter contained the same message as that which Johannes Renner published in his chronicle ${ }^{85}$ - wherein Duke Albrecht is urged to deploy a force of 10,000 with all speed -, then it does not concern the elucidations of 6 and 8 April cited earlier, but a letter from the start of May. Renner's text is word for word identical to a piece of writing of Archbishop Wilhelm from that month which has been preserved elsewhere ${ }^{86}$ This means that only then Galen and Fürstenberg received their definitive proof that the archbishop and the land marshal conspired to subject the Confederation to their own authority. They circulated this text and other intercepted letters extensively, both within the Order and amongst the bishops and cities that were members of the Estates of Livonia. Fürstenberg was thus able to strengthen his position and bring various supporters of Jasper and other doubters within the Order to his side.

The conspiratorial enterprise undertaken by Jasper and Archbishop Wilhelm seems to have been borne out of need, anger, and wishful thinking. The reaction of the advisors of the Polish king reporting to Duke Albrecht show that Jasper's part in the plan did not stand a chance even if his intentions had been kept secret. Sigismund II's councillors rightly noted how their king as protector and kin to Wilhelm

83 Regesten (as n. 5), no 1841 (April 8, Archbishop Wilhelm to Duke Albrecht). Compare two earlier surveys of all order castles in Livonia with their commanders, composed for Archbishop Wilhelm, cf. Regesten (as n. 5), nos 1711, 1751. The main castles of Jasper were Segewold (traditionally the residence of the land marshal), Dünamünde, Ascheraden, Mitau, Schujen and Lemburg.

84 Regesten (as n. 5), no 1628 (15.7. 1554).

85 Johannes Renner, Livländische Historien (as n. 74), pp. 9-10.

86 Regesten (as n. 5), no 1821 (Archbishop Wilhelm to Duke Albrecht, May 1556). It is striking that Master Heinrich von Galen in his letter to Duke Albrecht on the intercepted plans also refers to a message about an invasion of 10,000 military men, cf. Regesten (as n. 5), no 1852. 
did indeed owe support and help to the archbishop, but that he could perform in those duties equally well by pressuring the Confederation in political and diplomatic ways. On the contrary, the land marshal's case could only be resolved through force of arms, which brought great risk along with it. To the Christian neighbors and the Empire an act of war against a Christian institution had to be justified. Using violence would further open the door for allegations and suspicions of the king's greed and lust for the wealth of others. Added to that, interference with the Master's election would led to the indignation of various members of the Holy Roman Empire and the Deutschmeister. And last but not least, not enough forces were available to him. The king's best men-at-arms were stationed at the southern and eastern borders of his realm to repel any possible invasion by the czar or the sultan. In view of this King Sigismund II decided for the time being, to only send a diplomatic delegation in force to Livonia under the leadership of the aforementioned Caspar Luntzki. Luntzki was charged with putting as much pressure on the Confederation as he could to dissuade it from employing mercenaries and to further promote the archiepiscopal coadjutor's project. $^{87}$

So, Jasper had overestimated his potential support and his plans had been outdated by the time they were put to paper, simply because Galen and Fürstenberg had already taken the necessary precautions to resist them. This was shown at the end of April when Jasper commanded the assistant-commander ('Kumpan') of his main castle Segewold to move to Dünamünde with a significant number of men to inspect and reinforce the stronghold. ${ }^{88}$ The captain on duty at Dünamünde refused to grant the inspectors access, motivating his decision with the explanation that the land marshal should not be given any opportunity to cause unrest in the land in order for it to fall into foreign hands. ${ }^{89}$ Shortly after Jasper at Segewold heard of this mission's failure, he wrote a letter to the Master legitimizing his own actions and journeyed with a personal retinue of 20 men and 40 well-equipped knights to Ascheraden. But there

87 Regesten (as n. 5), no 1817 (5.2.1556).

88 Regesten (as n. 5), nos 1904, 1906 (without mention of month and day, but after August and thus edited by Hartmann at the wrong place). Jasper writes in his letter to the Livonian Master that the raid to Dünamünde has taken place vergangene Mittwoch. This letter can therefore be dated indirectly as May 1 at Segewold, cf. Regesten (as n. 5), no 1910/2.

89 This must have been before Archbishop Wilhelm's first letter on his 'action plans' was intercepted. It appears therefore that Galen and Fürstenberg had already brought Jasper's castles Dünamünde and Ascheraden under their control because of their strategic location (for actions against the archbishop). They seem to have considered Jasper as a disobedient Order's member and potential traitor since his public speech at the Wolmar diet and his refusal afterwards to recognize Fürstenberg as coadjutor. See Galen's notice in his letter to King Sigismund II of 15 mei, stating that he has let Dünamünde been occupied and guarded: Documenta ex Archivo Regiomontano ad Poloniam spectantia (as n. 6), vol. 10, no 1530, annex no I. 
too Jasper's company proved to be unwelcome. No reaction was given to his offer to the house commander there, Wilhelm Holthey, to leave six nobles in hostage. Jasper, who was thus refused entry into the castle, mentions how he and all his companions were forced to pass the night outside of the walls.

At that moment the land marshal would have realized that he no longer stood any chance of bringing the Order in Livonia to his side. Quite the contrary: it would not be long before Fürstenberg would commence the manhunt for Jasper with a force of a few hundred men. Jasper then, sent his 40 cavalry men to a manor on the other side of the Dvina with the instruction to travel to Lithuania from there. The land marshal and the rest of his band sought temporary refuge with Archbishop Wilhelm at his castle at Kokenhusen. He appears to have stayed there from 7 May to 11 May. He wrote letters there to the commanders Philipp Schall von Bell (Marienburg) and Heinrich von Galen junior (Bauske), both loyal to him, wherein he tried to explain his behaviour. Shortly after the evening meal on 11 May he decided to leave Kokenhusen, cross the river Dvina and journey to Kaunas to offer his services to the Polish-Lithuanian Wojwode Nicolaus Radziwill. He would have arrived there on 12 or 13 May, just before Fürstenberg's troops could close the border. ${ }^{90}$ His possessions and valuables had to be left behind at Segewold in a hurry. Archbishop Wilhelm mentioned in the plea for support on behalf of Jasper to his brother how the Order had deprived him of all his assets and silver.

\section{THE COADJUTOR FEUd AND THE SUBSEQUENT WAR WITH MOSCOW}

Jasper's escape had been an annoyance to the Order, but still nothing more than that. ${ }^{91}$ The matter of importance was that Fürstenberg could now fully focus on the struggle with Archbishop Wilhelm and his coadjutor Christoph. The intercepted letter with Wilhelm's requests for military aid to his brother Albert and the Polish king were used by Fürstenberg to rally support from the Estates of Livonia for his military action against the archdiocese. The mood in Livonia had turned highly antiPolish and anti-Prussian. This was shown when emissary Caspar Luntzki - who had been given instructions on 2 May by the Polish king to renew negotiations with the Confederation over the coadjutor matter, and to debate Jasper van Munster's positi-

90 His first letter from Kaunas dates from May 23, cf. Regesten (as n. 5), no 1833.

91 Of course Galen and Fürstenberg requested King Sigismund and the Wojwode Radziwill to hand them over the land marshall: Documenta ex Archivo Regiomontano ad Poloniam spectantia (as n. 6), vol. 10, no 1529, annexes 1 and 2 (both of 15. 5. 1556). A Polish corespondent reported at June 2 from Wilna to Duke Albrecht that the Order was unhappy [...] dass solchen fogell welcher alle ire thündt und hendel wais, aus dem lande geflogen, ibid., vol. 14, no 112. 
on - crossed the border in South East Livonia to journey to Archbishop Wilhelm. ${ }^{92}$ But, on the way to Kokenhusen Luntzki and two servants were killed by men of the Order's 'Vogt' of Rositten. This did not stop the Confederation from declaring the archbishop responsible for breaking the peace. The Confederation declared a feud against him on 16 June, after which one stronghold after the other was taken by Fürstenberg's troops. It seems that a number of the mercenaries hired by Kettler were employed in the military manoeuvers. ${ }^{93}$ The extra use of force was not really necessary, however, since the archbishop's men offered barely any resistance. On 29 and 30 June, Wilhelm and Christoph surrendered to the Confederation And thus the Order seemingly gained a resounding victory.

It turned out to be a Pyrrhic victory. King Sigismund II August of the militarily powerful Poland-Lithuania, showed restraint up until then, but he obviously could not tolerate the course of action taken by the Confederation against the Archbishop. Discussing the matter at the Imperial Diet was his first choice, hoping that Ferdinand I, who had succeeded Charles V after his abdication, would call the Confederation to order. Sigismund further invited a Danish delegation on the authority of King Christian III to try and secure rehabilitation and compensation for the archbishop and his coadjutor. Lengthy negotiations followed between the Estates of Livonia and Archbishop Wilhelm and Coadjutor Christoph, but although the envoy secured an accord on 10 March, 1557, Sigismund II refused to acknowledge it, apparently being not content with the result. ${ }^{94}$

The Polish king let an increasing number of troops congregate at the border with Livonia to demonstrate that he was both willing and able to intervene. In the meantime, diplomats sent by Ferdinand managed to secure an eight-week treaty, but when the terms of the treaty expired on 9 June, the Polish king sent a vanguard numbering an estimated 80,000 troops into Livonia. Fürstenberg, who had succeeded Heinrich von Galen as Master after the latter had died that summer, could not provide miltiary resistance capable of countering such forces. With the 7,000 men that it could command in its entirety, the Confederation was simply too weak to resist a combined Poland and Lithuania army. Fürstenberg understood as much. Whereas before the Coadjutor feud Fürstenberg had been exceptionally aggressive against Poland, now he was as meek as a lamb. In an attempt to avoid battle, Furstenberg entered into ne-

92 The first mention that Luntzki had been killed, dates from June 18, cf. Regesten (as n. 5), no 1844. The exact date of his death I was not able to retrieve.

93 According to some information Duke Albrecht disposed of, the mercenaries of the Order were - ironically - to be led by Jasper's brother Jurgen; he therefore requested Jasper to interfere with his brother to prevent him bringing the military together, cf. Regesten (as n. 5), no 1835 (6.6.1556).

94 Seraphim (as n. 4), pp. 219-221. 
gotiations with the king, being willing to concede to the majority of his demands. The power differential and desire to avoid war, naturally resulted in an expedient treaty. The Livonian delegation was admitted on 31 August into the Polish encampments at Poswol and the negotiations with regards to the coadjutor's issue were finalized on 5 September. Thereafter, the agreement was quickly ratified. As a result, Archbishop Wilhelm and Coadjutor Christoph were restored unconditionally to their positions and they regained their possessions. The only concession from their side was that the coadjutor had to swear an oath not to secularize the archdiocese. Furthermore, various emendations to the border in favour of Poland were accepted, amongst other to areas that had been violently defended by Fürstenberg during his time as commander of Dünaburg.

Much more important than the rehabilitation of the archbishop and the coadjutor was the additional alliance between the Confederation and Poland against Moscow, agreed to on September 14, without details as to how and when - in sofar as it would only come into force when the armistice between Poland and Russia was ended. It is with this agreement that Poland gained so much. It opened up the way for the czar to provide him easy access to Livonia, which in the short term meant that his pressure on Lithuania and Poland would decrease. This much was clear to all involved: this treaty was diametrically opposed to the treaty that the Confederation made with Ivan IV in 1554. The new treaty offered the czar therefore a legitimate reason to declare war on Livonia. And the treaty was signed just as the right time for potential Russian interference, as the czar was freed from other military ventures upon the cessation of his conflict with Sweden (March 1557).

Czar Ivan IV, who had followed the internal feud in Livonia and Livonia's subsequent conflict with Poland closely and had learned from the course of affairs that the Confederation's military might did not amount to much, was soon made aware of this treaty. He deduced that King Sigismund II would offer Livonia no help if he chose to invade. Neither could Livonia count on the Empire, nor would Sweden be an ally after Livonia refused to assist Sweden in 1554. Ivan did not hesitate to make haste with the collection of Dorpat's tributary payments, payments he knew Livonia could not possibly afford. In February 1558 he sent some 80,000 Tatars and other soldiers North. They first conquered Narva and Dorpat and subsequently destroyed almost all of Livonia north of the Dvina over the course of the next two and a half years. The Livonian branch of the Teutonic Order, and the bishoprics and the cities in the path of the Muscovite troops, proved utterly unable to offer meaningful resistance. More than the lack of manpower, they lacked unity.

The Polish king watched as these events unfolded. As he must have realized beforehand, he neither could nor would intervene as he could not risk open war with the czar. Only after Livonia had lost the battle at Ermes at the close of 1560, did the Polish 
king decide to act as protector of the archdiocese by occupying the region up to the Dvina. During this action he accepted the last Master of the Order, Gotthard Kettler who had deposed Fürstenberg on 17 September 1559 for calling in help of Denmark instead of choosing Poland - as a vassal with the title of Duke of Courland. In his new position, Kettler formally disbanded the Teutonic Order in Livonia with the permission of the Estates and discharged the members from their duties of obedience and other vows. Sweden, meanwhile, had appropriated parts of Estonia, Denmark received territories in the west of Lithuania, whilst Moscow more or less annexed the diocese of Dorpat. The resulting balance of power was far from stable, and in the following decades war was consistently on the agenda as these powers worked to sort out the Baltic question.

\section{JASPER VAN MUNSTER IN EXILE}

Given the fact that Jasper enjoyed the sympathies of the Polish king - who could have imposed his will on the Teutonic Order and the Confederation after all - the question arises how Jasper fared during and after his exile in Kaunas. The first problem posed to the land marshal after his arrival was of a financial nature. Duke Albrecht, who had been asked by his brother Wilhelm to assist Jasper, did not manage to find him a lucrative position. He would, however, vouch for a loan that Jasper wanted to enter into on the basis of the income from his paternal and maternal inheritance. Duke Albrecht furthermore relieved Jasper from certain obligations by taking over a number of his mounted soldiers and servants. The Duke also sent several letters with requests to the Polish king and his wojwode Nicolaus Radziwill at Wilna (Vilnius) to help Jasper and advised the latter to offer his services entirely to the king. Jasper did so. On 29 June 1556 Jasper received an audience from the king at Wilna and provided Sigismund II with information on the latest developments in Livonia. This included a discussion of his own position, as he requested the king to strive for the rehabilitation of his possessions and standing. ${ }^{95}$ The king declared himself to be willing to aid Jasper, although at the moment the king had little power in the matter. All he could do he made clear to Jasper was to plead for him by the Emperor and the Danish delegation.

By autumn Jasper was confronted with a major setback. His brother Jurgen, who would otherwise have supported him in council and in action, died on 23 September

95 Documenta ex Archivo Regiomontano ad Poloniam spectantia (as n. 6), vol. 13, no 180, pp. 147-148 (Wilna, 2. 7. 1556). 
in Aurich. ${ }^{96}$ Jasper seems to have journeyed down to Groningen in this time to settle the matter of inheritance with his kin and to discuss the consequence of his recent personal circumstances. ${ }^{97}$ The result was that one of his nephews wrote a letter to the Polish king with the request to support the land marshal in exile. ${ }^{98}$ The copy of this letter that has been preserved turns out to have almost the exact same contents as Jasper's own apologia that he had printed at the behest of Duke Albrecht at Königsberg on 3 January 1558. Royal representatives let Jasper know on 18 January that they had reported the content to Sigismund. According to the representatives the king had pondered all the points raised in the letter and had agreed to compensate the land marshal extensively for the injustices befallen on him. ${ }^{99}$

As the preparations for the war progressed in the spring of 1557 Jasper advised the king several times on how to best move forward the Polish military force into Livonia. Duke Albrecht also continued to recommend him in the care of the king. It is certain that the matter of Jasper's rehabilitation was placed on the agenda during the peace talks at Poswol by Sigismund's emissaries. It seems that the king even demanded of the Livonian Order that they acknowledge the exiled land marshal as Master or coadjutor. In practice this would not have been a reasonable demand. ${ }^{100}$ Fürstenberg must have succeeded in keeping the matter outside of the bounds of the peace treaty by promising the king to find an acceptable settlement for Jasper after consultation with his 'Gebietiger'. Various letters by Sigismund II refer to Fürstenberg's promise afterwards. Meanwhile Jasper understood all too well that the Master would never seriously pursue this because he still considered Jasper to be a traitor. In Poswol, too, he had made this clear by permitting his servants to shout abuse at the land marshal. ${ }^{101}$ When Duke Albrecht heard that little had been achieved for Jasper, he again wrote an extensive letter to the king with the request to reimburse Jasper. ${ }^{102}$ If he could not be restored to the office of land marshal, he ought to be offered the office of coadjutor or the preceptory of Fellin. And if those positions proved unavailable, then at the least a yearly fee of 3,000 Thaler ought to be paid plus compensation for all expenses he had incurred during his exile, expenses that amounted to no less than 10,000 Thaler in total.

96 Eggerik Beninga, Cronica der Fresen, vol. 2, ed. L. Hahn, Aurich 1964, p. 764.

97 At December 18 he gets erneut (anew) consent of Duke Albrecht to travel (via Prussia) to his relatives in the Low Countries, cf. Regesten (as n. 5), no 1955.

98 Undated letter: Utrecht, Archief van de Ridderlijke Duitsche Orde, Balije van Utrecht, no 157.

99 Regesten (as n. 5), no 1975.

100 Regesten (as n. 5), no 2087/1.

101 See Jasper's reply to Duke Albrecht to the - at least for him - disappointing outcome of the Poswol negotiations, cf. Regesten (as n. 5), no 2095 (26. 9. 1557).

102 Documenta ex Archivo Regiomontano ad Poloniam spectantia (as n. 6), vol. 35, no 4586, (7.10.1557), pp. 66-68. 
For the time being, however, all of this was of little help. At the insistence of the Polish king, Fürstenberg replied that he could only decide when the case had been discussed at a Diet; which in turn could not be convened in the near future. An envoy from Duke Albrecht commented that Fürstenberg consciously delayed the matter. Fürstenberg was reportedly frustrated that during Galen's tenure Jasper never once acknowledged him as lord and coadjutor. ${ }^{103}$ The king let Fürstenberg know in a reply from March 1558 that he could make true on his promises without consulting the Estates, to which Fürstenberg replied in April that he had taken his promise very seriously indeed, but that at the least he would need the consent of his 'Gebietiger', and that after the Russian invasion they could not possibly convene. ${ }^{104}$ Neither did encouragement from Emperor Ferdinand in June 1558 move the matter ahead. ${ }^{105}$ Intercession letters from Duke Albrecht were always answered by Fürstenberg in noncommittal terms.

Only when Coadjutor Gotthard Kettler had taken over the reins from Fürstenberg - in early 1559 he had operated for some time as governing master alongside Fürstenberg - could Jasper have any hope of true restitution. He met Kettler in April during his visit to Sigismund at Krakow, at which time the future division of Livonia must have been on the agenda. Given a report written to Duke Albrecht reviewing the meeting, Jasper wished Kettler all the luck and blessing with his new administration. Jasper also requested Kettler to restore his old dignity. ${ }^{106}$ Kettler is supposed to have promised him that as governing Master he would make every effort for Jasper, at least as long as Jasper was willing to support him with body, property and blood. Jasper, by the way, had indeed been promised financial support by the king, with the income from the toll at Kaunas. ${ }^{107}$ Sometime later, on 5 September, Kettler declared to emissaries from Archbishop Wilhelm and Duke Albrecht at Wilna that he would grant Jasper three manorial complexes with attending grounds, to wit Mitau, Ascheraden and Windau. He would also restore Jasper to his former status, aiding him in a variety of ways, including permitting him to bear the title of "old land marshal" in all official meetings of the Order and the Confederation. Kettler also confirmed that he was prepared to dismiss all antipathy towards Jasper. He would forgive him heartily for everything he had accused the Order and the Master of, on the condition that Jasper was prepared to turn against the Order in no way whatsoever. ${ }^{108}$

\footnotetext{
103 Regesten (as n. 5), no 2159 (February/March 1558).

${ }_{104}$ Regesten (as n. 5), nos 2202, 2204.

105 Regesten (as n. 5), no 2230 (30.6. 1558).

106 Regesten (as n. 5), no 2431 (10.5. 1559).

107 Regesten (as n. 5), no 2550 (23.5. 1559).

108 Regesten (as n. 5), no 2498.
} 
In practice, however, no one made good on this promise. Kettler did little more than transfer the minor house in Windau to Jasper, and not even that in its entirety: Jasper could not support himself, in his own words, because he returned to Livonia without his personal fortune. Urgent pleas to the king and Duke Albrecht were needed before Kettler was compelled to greater charity. Kettler kept using the excuse that, on account of the war against the Russians, he simply could not afford to give Jasper more. But even after the worst war years were behind him, the Master was reluctant to transfer the houses of Ascheraden and Mitau as he had promised.

In November 1561 Jasper complained once again to Duke Albrecht who continued his unrelenting support. Jasper wrote how, although Kettler honoured and acknowledged him as land marshal during a formal event in the presence of Wojwode Radziwill, Archbishop Wilhelm and the current bishop of Courland, his re-instalment was nothing more than smoke and mirrors, and was not followed through with active duties. After Jasper's return to Kaunas - he had not been able to settle in Windau after he had to give it in bond to the king in return for loans - it had become clear to him that Kettler had transferred parts of Ascheraden and Mitau to Radziwill, of all people. When he had complained over this course of affairs to Radziwill, the latter replied that "whomever can no longer wear the scarlet, has to be content with London cloth". ${ }^{109}$ In other words: the old land marshal had to pedal back his demands and be content with what he could get.

It would take years before Jasper, chased by debtors, could take possession of Ascheraden and other properties promised him. ${ }^{110}$ This exhausting restitution process can be found in detail in the several dozens of letters dated after 1561 that have been preserved in the archives of Duke Albrecht and the Polish king. For the sake of this article it is not necessary to discuss these letters extensively. What they show posterity is that Duke Albrecht, to his very death, fully and continuously supported Jasper. This was not just because of the support that the land marshal had given his brother Wilhelm during his conflict with the Confederation. It seems that Albrecht had genuine sympathy for the well-educated and ambitious Jasper. Be that as it may, without the unceasing and unconditional mediation of the duke, King Sigismund would have stopped his interventions in an earlier stage and Masters Wilhelm von Fürstenberg and Gotthard Kettler would not have cooperated in any way to the restitution of Jasper's honour. Because that much is obvious: between the lines it is clear that the Order's leadership no longer tolerated their competitor after he had been eliminated from power at the Diet of Wolmar in March 1556. The ostracism of Jasper occurred not just because of his pro-Polish position - Kettler himself also

\footnotetext{
109 Regesten (as n. 5), no 2899 (November 1561).

110 Ritterbrüder im livländischen Zweig des Deutschen Ordens (as n. 25), no 604.
} 
relied on Poland in the end - but on account of his disobedience. By refusing to acknowledge their choice of coadjutor, Jasper had broken the single code that kept the Livonian branch of the Teutonic Order together as a brotherhood.

Unlike Fürstenberg, Jasper van Munster did not end up in Russian captivity. Ironically, his exile in Kaunas managed to prevent that. Yet Jasper did die by their actions at the end, in 1577 when the castle of Ascheraden was taken by a Russian army unit. ${ }^{111}$ His nephew Johan, former cathedral canon of Riga who accompanied him there, was taken in captivity but managed to survive, returning to Lithuania in 1585 , after a prolonged captivity.

\section{Epilogue}

How should Jasper van Munster be judged in the end? As an evil genius whose schemes and intrigues brought the Confederation and the Livonian branch of the Teutonic Order to the edge; as a far-seeing prophet who went unheeded; or as a touchy, arrogant and stubborn order dignitary who thought support from his fellows was trivial to his intentions? Can he be really hallmarked as a traitor? His letters and those of the archbishop to Duke Albrecht and the Polish king that were intercepted in May 1556 show that he indeed did plot to turn against the Confederation and the Order's leadership by force of arms together with Archbishop Wilhelm. This can be called a conspiracy. Wilhelm von Fürstenberg, at the time coadjutor beside the weak Master Heinrich von Galen, took every effort to make the matter public and spread the news of Jasper's disobedience far and wide as proof of the treachery that Jasper and Archbishop Wilhelm had already been accused of. Given the resistance against Jasper in Livonia after 1557, Fürstenberg was evidently successful in his endeavours.

As for the charge of treason, however, two important comments need to be made. Firstly, the plot in question has the character of a scheme that never left the drawing board and did not stand a chance in reality. The opinion of the Polish king's councillors concerning the plot leaves this beyond a shadow of doubt. Secondly it turned out to have only been drafted after the Diet at Wolmar (15 March 1556), when Galen and Fürstenberg had long since taken measures in secret to take out the land marshal and the archbishop by military means. It can be concluded from the sequence of events that the initiative to take up arms came from Fürstenberg and his compatriots and not from Jasper and Archbishop Wilhelm. The conspiracy of Wilhelm and Jasper and its attendant 'discovery' gave Fürstenberg a much-needed excuse

111 Die Grafen von Münster (as n. 8), p. 95. 
to garner public support for the anti-Polish course of action that he had set on much earlier, and which had to cost the Confederation its defensibility with regards to the Russian threat. It was Wilhelm von Fürstenberg who was the skipper that sailed the ship of the Confederation on the cliffs.

It can be debated if, and if so to what degree, Archbishop Wilhelm's politics for the secularization of his archdiocese, which were strongly supported by that Duke Albrecht, gave Fürstenberg extra leeway to draw the Order's leadership to his person and pursue his own course within the Confederation. Were the Archbishop's actions, given the circumstances, too provocative and therefore partly responsible for the eventual course of affairs? It is hard to answer that question. As for Jasper, it is clear that he supported the politics of the brothers Brandenburg-Ansbach completely. There are, however, no clues that he was driven by the ambition to secularize the Order state after he would have become Master. Unlike Gotthard Kettler, by 1555 he was too old to found a dynasty for himself. His conduct seems to have been inspired by his desire to keep his honour and good name, as well as his concern for the threat of what he perceived as an unchristian Moscow.

\section{SumMARY \\ Traitor to Livonia? The Teutonic Orders' land marshal Jasper van Munster and his actions at the outset of the Livonian crisis, 1554-1556}

One of the main factors contributing to the collapse of the Livonian Confederation in the 1560 's was the disagreement within the Livonian branch of the Teutonic Order over the course of action and response to the Russian threat and the power play of young Ivan IV. The Dutch born Land Marshal Jasper von Munster, the pre-eminent candidate to succeed the aged Livonian Master Heinrich von Galen, was convinced that Livonia could only maintain itself against the new tsar if it entered into a prolonged alliance with Poland, accepting a partial sacrifice of its autonomy. He met with fierce opposition from a group of Order's dignitaries, led by Wilhelm von Fürstenberg, who opposed any rapprochement to Poland.

This paper examines why Munster was defeated even though his political line proved to be the soundest. The study adopts a biographical approach and focuses on the Land Marshal's actions in the opening phase of the Livonian Crisis in the years 1554-1556. It is argued that initially Munster did not plot against the Order's leadership together with the archbishop of Riga Wilhelm. This happened only in April 1556, long after Fürstenberg had convinced Master Galen and the majority of the Order's officials to support him by acting as coadjutor before he had been formally elected to that position. The prevailing assumption in Baltic historiography that Munster had 'treacherously' aimed to secularize the Teutonic state to become its new ruler has to be rejected because Munster at that time was too old to start a dynasty. His actions, though tactically clumsy, seem to have been motivated by genuine concern over the threat of unchristian, in his eyes, Moscow. 